SF 385

. A42

Copy 1

Angora

Goats

\title{
The Wealth of the
} Wilderness 



\section{The Wealth of the Wilderness}

\section{BY GEORGE EDWARD ALLEN}

"THE STONE WHICH THE BUILDERS REFUSED IS BECOME THE HEADSTONE OF THE CORNER."

WELLSBORO, PA., U. S. A.

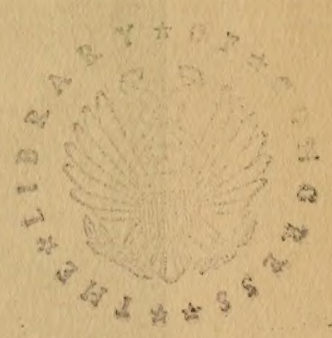
HORACE A. FIELD \& COMPANY

I 900 


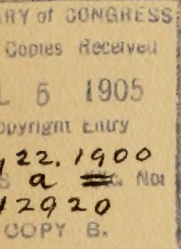

$\because \vdots \vdots$

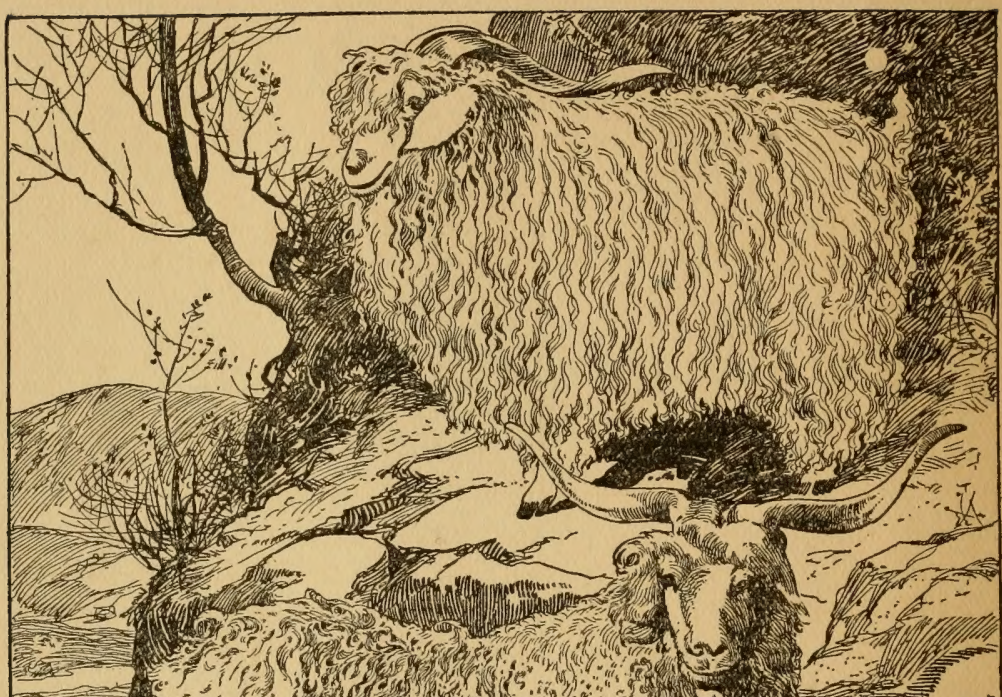

4. (4) 1. - 1.7. 1. 7.7.

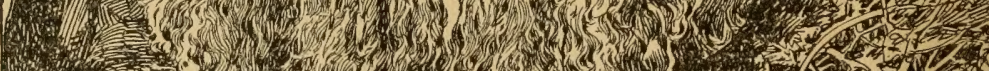

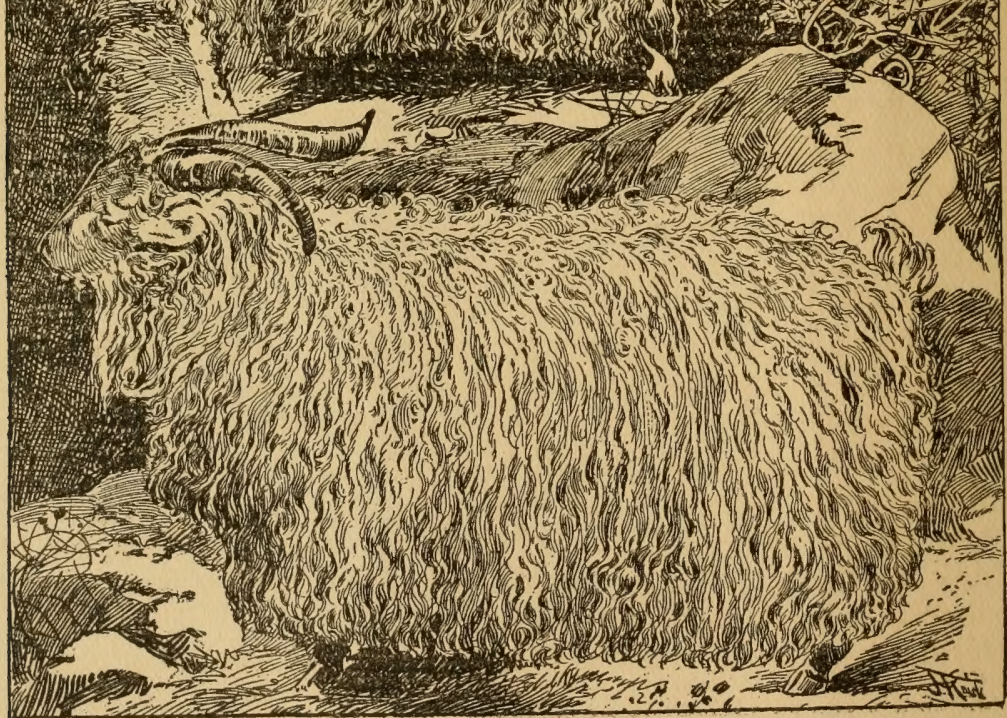




\section{ANGORA GOATS}

CHAPTER I.

Scrub Uplands and Their Utility.

Millions of acres of land in the mountain districts of America and along the great lakes are overgrown with brush and weeds. For ordinary industrial purposes they are worthless. A permanent revenue of even a few cents an acre from this vast territory would add millions, if not billions, to the wealth of the country. A cent a year from a piece of land as large as a city lot does not seem like much money, but on a valuation of a dollar an acre, which is a liberal figure for brush and stumps, it is a greater percentage of profit than is realized from the best improved property in New York City.

In building railroads, developing mines, conjuring with electricity and making farming an advanced science, American genius has overlooked primitive opportunities in which nature does most of the necessary work and requires the minimum of capital and experience. The highlands of America are exactly adapted to raising rugged breeds of cattle, sheep and goats, such as inhabit the mountainous regions of the Old World, and constitute the most substantial wealth of Scotland, Turkey and South Africa.

Every living creature is an evolution of environment. The highlands of Scotland have developed the famous Cheviot and Blackfaced sheep, which thrive where no other domestic animals can live, and the rugged Galloway hills have given their character and name to a breed of cattle unequalled for hardihood and unexecelled for profit. The barren uplands of Turkey in Asia are the home of the Angora goat, which can subsist on the nearest to nothing of any animal useful to man. The climate, soil and vegetation of the mountain and forest districts of Ameri- 
ca are seemingly more suitable to these rugged animals than their own native lands, and unlimited opportunities are available for capital and industry.

In advocating distinctly highland breeds of live stock for highland districts no reflection is implied upon the masters of breeding who have stocked our cultivated fields and fertile prairies. America has out-Jerseyed Jersey and out-Merinoed France and Spain. The methods of the cultivated fields and prairies, however, are not the methods of the mountains, and the animal character of the plains is not the animal character of the highlands.

When Uncle Sam had free farms for all comers, with climate and soil to suit individual preferences, animal industry consisted chiefly in finding proper locations for breeds sufficiently profitable to overbalance the expense of special care and feeding. Such locations are now occupied, and in addition to the ordinary profits of stock raising there has been a substantial increase in the value of land thus utilized. Even the Western ranges have attained a recognized worth and are rapidly passing into private ownership.

In figuring the financial results of stock raising, interest on the value of land must be allowed and the expense of care and feeding must be taken into account. As land in favored locations increases in price, opportunities previously rejected or overlooked must be utilized. Profits and losses depend upon the capital and expense accounts. The time has come when the stockman must adapt breeds to locations instead of hunting locations for breeds. Under such conditions the reclamation of American highlands is no longer a sentiment. It is a practical business proposition.

"The stone which the builders refused has become the headstone of the corner." This ancient adage applies with striking aptness not only to neglected highlands overgrown with brush and weeds, but to the agency which nature has provided for their reclamation. That agency, inexpensive and unfailing, as natural agencies always are, is the goat. Any kind of goat will clear brush land, but as it costs no more to maintain good goats than poor ones, Angoras and grades of this breed are recommended when obtainable on reasonable terms. This idea is of course very simple, as all great things are simple when you 
come to understand them. When you consider the square miles and square hundreds of miles of wilderness that may thus be made valuable, the magnitude of the idea grows upon you.

Government authorities estimate the amount of unproductive land in the United States at $265,000,000$ acres. Relative to areas suitable for goat keeping upon any scale, from a few for milk or cheese to large flocks for their fleeces or skins, it may be confidently asserted that wherever there is a suitable climate there are also suitable uncultivated lands. Over 42 per cent. of the land in farms in the United States is unimproved; how much of it is uncultivable is unknown. The total unimproved land amounts to $265,000,000$ acres, against more than 375,600 ,ooo improved. This presents a vast field for selection of favored localities in every part of the country.

It is true that considerable portions of the unimproved farm land is in valuable forests, which invite preservation as such for various economic reasons; but it is equally true that a large proportion is useless as a present or prospective timber reserve, and can be utilized only in some such way as here suggested. In the aggregate, millions of acres of poor, rough, rocky, or bushy land, distributed through all the States, call for subjugation and enrichment through animal occupation, preferably of the goat, which would not only destroy the growth that invites recurrent conflagrations, but would result ultimately in the introduction of nutritious grasses.

The goat is easily adaptable to all countries, and thrives in all climates except that of the polar regions. Evidently, however, it will tend to be most profitable in those localities where the expense of keeping is the least the year round. Hardy, agile, enterprising, it always thrives, if unconfined, in heat or cold, on mountain or plain, but prefers rough, rocky, wild and elevated land.

\section{CHAPTER II.}

\section{Government Investigations.}

The United States Department of Agriculture, at all times and very properly conservative, has recently and for the first time given serious attention to goat culture. In a bulletin writ- 
ten by Almont Barnes of the Division of Statistics, some interesting statements are made. Goatskins, from which is derived the greatest amount of the profits of goat keeping in regions where the largest numbers of these animals are usually raised, were in so little demand in the United States prior to 1864 that they were not separately classified for duty on importation, but were included with "hides and skins" of all kinds, except fur, which together were valued that year at $\$ 7,505,238$, and paid an import duty of 5 per cent. ad valorem. In 1864 goatskins were first separately classified, being valued at $\$ 1,799,166$, while the imported "hides" were valued at $\$ 6,177,512$; and this is the starting point of their distinct and officially stated invoice value. In 1865, with the duty doubled, importation diminished; but under succeeding demand and rates of duty, or, as now, duty free, up to June 30 , 1898 , importation had increased in value to \$I5,776,601 , and the increase of the fiscal year 1898 over 1897 was 28.2 per cent.

The foregoing are, as stated, invoice valuations, that is, those declared as the cost to the shipper at the foreign ports of shipment. For various reasons, as of insurance, handling, freight, commissions, profits to the shipper, etc., they are much below the valuations in our own markets. The average invoice value of desirable skins in 1898 appears to have been 24.3 cents per pound- $\$ 15,776,601$, the invoice value, being divided by the invoice weight of $64,906,485$ pounds. But the average market price (the price to purchasers for home use) of these skins in New York during the year of their importation was about 39.3 cents per pound, or about 62 per cent. higher than the invoice value; so that the gross value of the year's importation, upon the basis of the average price in our home market, and at 62 per cent. above the invoice value, was $\$ 25,508,249$. This is what the consumers really paid, and it is therefore the real value of the skins imported, rather than that expressed in the invoices.

Practically all the goatskins entering into the commerce and manufacture of the United States are imported. With the exception of that portion of the population and its increase mostly upon territory derived from Spain and Mexico, the people of this country have not usually evinced any interest in goat herding for profit, either of skins or other products. There have been for centuries small herds in the sparsely populated western 
territory indicated, and, besides, a not inconsiderable number of goats in the aggregate has been kept for milk in the suburbs of cities.

In goat keeping on a large scale it is not alone the skins and fleeces which enter into the account of profit, although these are primary, especially for distant markets. If the skins, which represent over fifteen millions of invoice and twenty-five millions of market value in importations, represented native stock, there would be taken additionally into the home market and possibly profit account nearly the whole animal-the flesh, tallow, bones, hoofs, horns, and perhaps the intestines and their contents, which together may constitute half or more of the entire marketable value.

These specified objects roughly, but perhaps sufficiently, indicate the classes of domesticated goats prevalent in various countries, and inferentially the conditions attending their prevalence. As the greatest market demand is for skins, the largest herds in various countries are kept to meet that demand, and as the demand relates less to breeding than to abundance, the common goat (that least modified from the native stock) most economically and profitably meets the requirement. Common goats need the least care and require only the cheapest and most primitive pasturage-bushes and weeds. They furnish a product of world-wide use, not dependent upon any kind of culture for its availability or excellence. Wherever they can be stocked upon unused or otherwise unusable lands, with the rude and slight care required, they are almost gratuitouslv profitable. Thus, the price paid for imported goatskins is less representative of cost of production than of the commercial sagacity of the producers and their appreciation of the needs of the market, ard suggests an enviable margin of profit. The price above cost paid by consumers of this country is the gratuity paid to foreign producers, importers, etc., because of lack of enterprise, ignorance, or wasteful prejudice. The market price of an article is sensibly affected by nomenclature. In coffees, for instance, an additional price is paid for the names of Mocha and Java, though official statistics show, and facts of production and movement confirm, that not a pound of Mocha coffee has been introduced into this country for at least fifty years, and, compared with the supposed consumption, but little of Java for 
twenty-five years. So also are paid higher prices for so-called Curacao kid and goat skins and goods, while the arid island of Curacao, not 15 miles long nor 4 miles wide, having but two fresh-water springs and not 5,000 goats, receives its supplies of skins from adjacent parts of Venezuela and Colombia, which make Curacao their foreign shipping port.

Common goats are, of course, the most numerous class wherever skins are the principal object sought, and they furnish, besides, the milk and meat required by their owners or keepers. Next to these in aggregate number are the goats kept primarily for dairy products, in flocks or singly, over a large part of the world. This class includes select common stock, just as numbers of American dairy herds are made up wholly or in part of select cows from stock not artificially modified; but in particular it includes certain strains naturally possessing high milking qualities, as the Nubian, and kindred or similar breeds of Bengal and China, to which must be added classes bred with continuous care to the same end, as the goats of Malta, France, Switzerland, and, in recent years, of England. The Nubian and Bengalese goats are said to be much alike and most excellent. dairy breeds, but unfit to stand exposure in cold countries. Some have a record of nearly a gallon of milk per day while in full milk.

The Agriculture Department summarizes the subject of "Keeping Goats for Profit" as follows:

(I) The United States imports a large and steadily increasing amount of goatskins for necessary use in home manufactures and produces comparatively none. The invoice value of these imports is at present over \$I5,500,000 a year and the market value probably over $\$ 25,500,000$.

(2) There is an aggregate area of over $265,000,000$ acres of unimproved farm land outside of Alaska and recently acquired dependencies (more than the area of the original States and the Louisiana Purchase), a large proportion of which is suitable for the maintenance of goats. Being surplus farm land relative to present cultivation, this land is distributed evenly with the regular rural labor of the country. It also, according to location, embraces the climate of all the country except, as stated, Alaska and the new dependencies, which nowhere is dertimental to animal industries generally or to goat keeping in 
particular. The general features of land, labor, and climate, therefore, and of distribution are singularly favorable.

(3) Over $162,000,000$ acres of this unimproved farm land, or over 6 I per cent. (nearly as great an area as that of Texas) is the agriculturally unproductive surplus of farms of a continuous area having more than average favorable conditions as to relative amount, distribution of labor, and climate. This area is contained in the South Atlantic and South Central and a part of the Western divisions of the country. It now contains nearly all the herds of common and specialized breeds of goats kept by the people.

(4) All the favorable conditions are emphasized in much of the large area containing the densest negro popuiation by reason of the class and abundance of the labor element and circumstankes which render the adoption of an additional or new rural industry casy and undisturbing. They are also strongly emphasized by the prevalence of mountain chains through much of the area, and these are the favorite pasture ranges of the goat.

(5) The general and special favorable conditions herein shown are verified by all the testimony of goat raisers, some of which has been given, relating to Angoras and to goats for milk. Altogether the evidence seems conclusive that it would be easy and relatively inexpensive to furnish the home market with the increasing millions of dollars' worth of skins demanded year by year in our manufactures and so far furnished by countries which buy little from the United States. As the by-products of goat keeping may be made to cover all its cost, the value of the goat products now imported (more than $\$ 25,000,000$ per year) is a clear premium offered to their home production, a premium to rural industries.

\section{CHAPTER III.}

How to Clear Brush Land.

Goats are by nature browsers and not grazers. They can be depended upon to destroy the many undesirable products of cultivated and fallow lands, the abundant and persistent weedy 
vegetation which so incessantly besets the cultivated crops. Other domestic animals prefer the cereals and grasses which depend upon the labor and care of the husbandman. What these reject goats prefer and cheerfully pass by growing grass and grain for a constant dessert of wild carrot, burdock, mullein, or for thistle or cactus. Goats thus voluntarily clean fields of their vegetative refuse before it ripens and scatters its seed; and so persistently and impartially is this done that the latent seeds of valuable grasses, improving the chance thus given them to sprout and thrive, often follow the second or third year of good pasturage with a uniform carpet, clean as if made to order.

Dr. J. R. Standley, of Iowa, is the leader in land reclamation by the use of Angora goats. "Land can be cleared of the worst brush known to this country," says he, "for a little less than nothing, by Angora goats. Some one asks how. Simply this, Angora goats will pay a profit and live on leaves and weeds, leaving the land cleaner and nicer than can be done in any other way. Many persons have the idea that goats bark the trees and in that way kill them. They also think that goats wholly eat the hazel and other small brush. There is nothing in this. Goats are no worse to bark trees of any kind than sheep. The way in which goats kill brush is by continually cropping the leaves, which serve as the lungs of the brush. The continued cropping of the leaves makes the brush as it were sick, caused by lack of nourishment. This sickness sinks to the very extremity of the roots, thus preventing sprouting. Any and all kinds of bushes are in this way easily killed. Some kinds of brush and some kinds of stumps are of course much harder to kill than others. Many varieties are entirely killed by one summer's trimming of the leaves. Almost any are killed by two years' trimming. To clear the worst brush do not cut anything that the goats can reach or bend. The tallest or largest hazel is better not cut. All trees and saplings should be cut, and the goats will keep all the sprouts down. If stumps are allowed to sprout one year before the goats are turned in, the sprouts need not be cut. About 200 goats for forty acres of brush will in two or three years make the land as clean as a garden. If the pasture has only patches of brush, turn in a few goats and it will make more grass for other stock than if the goats were not in. They eat very little 
grass when they can get leaves. Goats even lilic weeds better than grass. In clearing brush land in the old way by grub and plow, there are always left many eyesores in the way of brushy nooks and bends and steep places which cannot be plowed."

"There are millions of acres of land in nearly every State in the Union," says Dr. Standley, "which might be much mòre than doubled in value by the use of Angora goats at no cost at all. Commence and count the worth of your land, then the fencing, and see if you can afford to leave your brush land so nearly worthless for all time. Then count the cost of grubbing and plowing, if indeed such land is susceptible to the plow. No man can afford to grub and plow brush land in this day and age of the world, any more than he can afford to plant a large field of corn without a planter. In hilly or mountainous portions of country, the Angora goat can be made to do a great service in the way of clearing the underbrush when the land will bring grass after the brush is gone. It would surely be a paying business to buy up large tracts of rough land in the mountain districts, or indeed any brush land in the United States, and clear the brush and set in grass. Aftervard, if the owner liked other stock better he might dispense with the Angoras. In many places where the country is too bare to furnish sheep with sufficient feed, goats will do cxceedingly well. In many places where leaves are abundant and there is scarcely any grass, making it impossible to profitably keep sheep, goats will do admirably well."

Col. William L. Black, in his comprehensive treatise on "The Angora Goat and Mohair Industry of the United States," says: "The brush question is a most serious one in a great many of our States. As long as land can be kept under cultivation the brush can be kept down; but, when it is once thrown open to pasture, briars and brush of all description begin to grow, and soon cover the entire surface. Even in our own State of Texas many millions of acres in the West are growing up into brush thickets, and will, sooner or later, become worthless for pasturing cattle; and, in many of the Western Territories the same conditions exist. It is supposed that this has been produced by an increase in the rainfall; but, I am inclined to think it is not altogether due to this fact. That brush and trees are indigenous to many of our, so-called, arid districts can be 
very easily proven by the great quantities of roots that the present inhabitants dig out of the ground for fuel purposes. Not a tree can be seen for hundreds of miles, yet these great roots can be found almost everywhere, on the prairies, and are a substantial witness to the fact that there was an abundance of trees there at some time or other. Before this portion of the United States was occupied by the white man it was a common practice of the Indians to burn the high prairie grass every fall, or winter, in order to hunt wild game that was so abundant in this part of the country. Buffalo and deer were as common then as cattle and sheep are now, but the grass was so high, in places, they could not be seen, and the Indian would burn it off to be able to hunt them more readily. This, undoubtedly, destroyed much of the growth of trees; and, in my opinion, is the true explanation of the roots that are now found in many parts of west Texas, New Mexico and other Western Territories.

"The question is a very important one, and if the goat can be used to keep this growth back it is certainly well worth the attention of many of our land owners, who may, in a ferv years, find their land practically worthless. A personal friend writes me that: 'many pastures are growing up to oak brush and hazel brush in the north; and in New England they are bothered with ferns (called brakes), berry bushes-blackberries, raspberries, etc.' This kind of fare would be 'peaches and cream' to a goat, and in a year or two the owner would be relieved of a great nuisance, the goats would grow fat, and the land would be restored to a proper condition for grazing other stock on it. Another correspondent in Massachusetts speals of a certain small island that he owned which was so densely covered with brush as to be utterly valucless except to grow mosquitoes. I hear of many parts of the East that are seriously troubled with brush, where many thousands of acres are of no use for grazing purposes, and the profit in farming will not justify the cost of grubbing it. In the Southern States many farms have become worn out and are growing up into brush and weeds. The Angora goat is the proper animal to employ to put these lands in a condition either for cultivation or grazing cattle. But a number of my correspondents have asked me what they could do with the goats after they had cleared their land. In reply to this I 
will say they can well afford to slaughter them and feed them to hogs, but this is not necessary now. The fashion has changed since I slaughtered goats for their hide and tallow, and there is no trouble in selling all the goats you send to any of our large meat packing markets."

\section{CHAPTER IV.}

\section{Practical Goat Raising.}

Special interest attaches to Dr. Standley's Angoras from the fact that he purchased, after the death of Colonel Peters, the remunt of the flock founded upon the original importation from Turkey. "Nearly all the Angoras in the United States are grades," says Dr. Standley, "having been produced by crossing Angora bucks and the common Spanish goats, the first cross being nearly all white and much longer haired than the common goat, but not producing enough hair to pay for shearing. The second crosses (three-fourths blood) are much better and often shear one or two pounds of not very good hair. The third crosses (seven-eighths blood) are almost as good as pure bloods so far as meat and hair are concerned. Of course these seveneighths blood bucks should never be used for breeding, as they are said by those best versed in the business to soon run back to the common goat in their progeny.

"Angora goats require much the same care as sheep and much the same feed except that goats are not so dainty and will eat much coarser feed. They eat coarse hay and straw and corn fodder about as sheep, only cleaner. Experience has shown that wherever sheep will thrive Angora goats will do well. Angoras are not grazing animals like sheep, but browsers. They prefer leaves and weeds to nice grass. In fact they run over grass to get leaves and weeds. Goats eat leaves and weeds for feed and then grass as a condiment. Sheep eat grass for feed, then a few weeds for condiment. Angoras dislike rain and mud, though cold and even snow they care not for. In portions of the country where the rainfall is abundant and the soil of a nature to 
get muddy, goats should be supplied with open, dry sheds. I believe the better way is to have sheds so that the goats can be shut out at all times except during wet storms. I have adopted the plan of only housing in time of storms, and even then the house should be well ventilated and not too much crowded. If the goats are made too warm by crowding and imperfect ventilation, they will sweat, and then when exposed to the cold become chilled. It is better not to house at all than to house badly.

"Angora goats may be bred any time from August Ist to February Ist as suits the condition of the owner. April is a good month for kids to come in. In this part of the world (Iowa), I now have adopted December as a breeding month. This makes the kids arrive in May, and in this climate they need but little attention at this season of the year. I like to have one buck for twenty-five does. By having one to twenty-five they will nearly all drop kids in one month. With one buck to fifty or more does they will not all get with kid so early and it will take two months or even more to get through the kidding season. If a short kidding season is no object it is possible to begin mating early and one buck will do for seventy-five does. The better way, if it can well be done, is to let the bucks in at night and put them in the barn or house and feed and care for them through the day. The does breed but once each year, and if well bred not many will drop twins.

"Shearing should be done before the hair begins to shed. I aim to shear the first half of April, and if the season is a little early it is sometimes better to shear earlier. Whenever the grass starts in the spring and the goats get at it they will in a few days begin to lose their hair. When the hair commences to slip it takes but a short time to loose the whole fleece. The goat ran be held and shorn the same as a sheep. It is better for the operator to be an ambidexter, as he then can clip against the hair on each side of the animal. If he is only right handed one side of the goat will necessarily be cut with the hair (I mean with the lean of the hair). This will leave some very long stubble. When the fleece is off roll it up outside out and tie with twine. The ordinary flock of well graded goats will clip about two to three pounds. With thoroughbreds from four to five pounds are often averaged. Many shear from eight to twelve pounds. Does, 
however, seldom produce more than from six to eight pounds. I am sure a flock of wethers might be made to shear from six to eight pounds on an average. Wethers shear much heavier than ewes. Mohair brings about two and a haif or three times as much as wool in the dirt, but goats do not shear more than about half as much in weight as sheep.

"To breed grade ewes, always breed to the best bucks obtainable and from pure bred flocks of reliable breeders. This cannot always be done. Pure bucks cannot always be obtained. Colonel Richard Peters, who was one of the most successful early breeders of Angora goats, says that half-blood females can, with the best results, be bred to their own sires provided the sires have proved themselves to be good breeders.

"Goats have cattle diseases more than sheep diseases. They never have inflammation of the mucous passages, and seldom have foot rot. They never have scab, but are frequently lousy. I have often read about putting a few goats with a flock of sheep as protection against dogs. Dogs kill goats but not so much as sheep. I have never had any old ones killed but have had quite a number of kids killed by dogs. Goats are somewhat harder to fence than sheep, but not so hard as hogs. Goats do not jump, but climb and creep. I have old-fashioned rail fences that turn goats perfectly. If a rail fence is made to lean from the goat he will climb it, no matter how high it may be, but a well built rail fence three and a half feet high, will keep goats perfectly. A seven-wire fence, properly spaced, will turn them perfectly. Two feet of woven wire and two wires above is perhaps the best. Goats bear flocking much better than sheep. In the range countries they are generally kept in flocks of from one thousand to four thousand.

"I read often of the necessity of an infusion of new blood into our American flocks by importing from Asia. I have serious doubts if Asia has as good Angoras as the United States. The people of that country do not select and breed with any care. I believe that we have already in this country Angoras from which a most superior animal may be produced by American ingenuity in selecting and mating, as has been done in the case of the American Merino sheep and the standard bred horse. While I am not averse to the introduction of new blood, I do not want it of an inferior quality. 
"It is now established beyond question that the Angora goat will do well in almost any part of the United States. The higher and dryer, the better. This to the flock master means much. I believe the time not far away when the Angora goat will be as common in the United States as the sheep, and as much prized. While I believe this I do not believe the goat will ever be substituted for the sheep. The mission of the two animals is very different. The sheep is better in his place. The Angora goat better in his place. There is room for both and many thousand more of each."

\section{CHAPTER V.}

\section{Live Stock and Location.}

W. G. Hughes, one of the leading stockmen of Texas, writes: "What class of live stock is most profitable?" How frequently does one hear this question asked by interested parties, and the pros and cons discussed in their various phases, without reference to the all-important one of character of the range involved. Perhaps this will tend to throw light on the fact that the distinctly highland types of domestic animals have not hitherto received adequate recognition at the hands of our more intelligent and well to do breeders. In our comparatively new continent there has been no great difficulty in obtaining for settlement and occupation, what have been regarded as the 'best lands,' by those who have had a reasonable sufficiency of means for securing them. By the 'best lands,' it has come to be understood, are meant those which have rich soils, generally speaking, bottom lands. The more hilly and rough areas, especially those which are largely covered with scrub brush, have been regarded as comparatively worthless, and have lain to a great extent unused, or have fallen to the lot of those who are not striving for superlative achievements, and who, by the same token, are not, as a rule, built to leave the beaten track of stock raising, and put such lands to their logically best use. Even in fairly well settled sections are often to be found large areas of hilly and broken country, covered with a stunted growth of herbage, which are still regarded as of but little value. In view 
of their accessibility and cheapness, the question naturally arises 'to what use can they be put to get the best returns from the vegetation they produce?' They can only be used to a limited extent for the support of horses or cattle, or even sheep, and are as a rule at best only useful in a supplementary way for this purpose.

"Of late years it has been dawning on many of those who have had access to this character of range, that the Angora goat, as a medium for the proper utilization of such lands, has been largely overlooked. The breeding of these animals has been for many years one of the leading industries in Cape Colony, South Africa, and it is fair to say that the interest and intelligence devoted to them in that part of the world almost parallels that given by our breeders to the leading breeds of cattle and sheep in this country. What we would regard as fabulous sums have often been paid for imported Angora goats at the Cape, and are still paid for noted individuals by prominent breeders when buying home-bred goats from one another. It is generally admitted now that painstaking care has resulted in producing a standard of greater excellence in the Angora goat than exists in the country of its nativity. Just as we in this country have so improved the Spanish Merino sheep, that we would not now think of making further importations from Spain. By judicious selection and breeding, there are now many thousands of well bred Angora goats scattered throughout the Western and Southwestern States, principally in Texas, to which many of the original importations into America went, and among those who have handled them for a series of years, they are no longer regarded in the light of an experiment. Their excellent and valuable qualities are rapidly becoming better known in a more general way. One of these characteristics is their adaptability to lands which have been hitherto regarded with so much disfavor. On these, where there is an abundance of underbrush, the goats are in their element. The Angora is essentially a browser, and while it will thrive on grassy land, it feels much more at home among. hills and scrub brush, and on such a character of range will attain its highest development. It is of an active temperament, which prompts it to travel over a good deal of ground in search of its food, and for this reason, while it does not in any way interfere with other stock, it does not like to be herded in the same 
flock. Sheep, for instance, are too slow in their movements to suit goats, which cover more ground in a day and are more inclined to herd in one bunch and less addicted to scattering. However, exceptions to this rule sometimes exist. Where a few goats are kept among sheep not herded, the goats will often, for the sake of company, stay with the sheep. They are useful in this connection, as goats almost invariably come home at night, and sheep follow them in, thus often avoiding the danger of having any of the flock killed by dogs or wild animals at night. Sheep and goats do not interbreed and so can be allowed to run together with impunity.

"Where range of suitable character exists, a pasture of any given capacity can carry a flock of Angora goats without detriment to other stock, because the goats will eat brush and weeds which other stock refuse, and will also enrich the more open land with their droppings, derived from a class of food which would otherwise be wasted. Where confined to a limited area they will effectually destroy underbrush by keeping the leaves eaten off. They are sometimes kept with this object in view, though most breeders who realize their value, give them access to ample brush, which they regard just as a sheep man does his grass, and for the same reason would not wish to graze it so closely as to destroy it. Angora goats will live largely on the twigs and bark of sappy underbrush and the leaves of evergreens in winter, and are rarely fed in the South at any, time of year; but in more northern latitudes, where feeding and sheltering are necessary, such provision as is usually accorded to sheep will more than suffice to keep Angora goats in the same condition. The meat of the Angora goat is excellent and is not distinguishable from mutton of the same age and condition. It is very largely sold as such in many of the larger markets, besides being regarded as a staple in the districts where it is raised. The methods employed in handling Angora goats are in the main very much the same as those followed with sheep. They can be herded in about the same sized flocks in mountainous ranges as sheep can in more level country. The most marked difference in the system of management is through the kidding season, when, instead of allowing the newly born offspring to follow the dam, as is the case with sheep, the kids are kept back in the pen 
when the flock goes out in the morning. It is not until they are about two months old that it is safe to allow them to run freely with their mothers, as the latter cover too much ground for the strength of the kids. During the earlier weeks of the life of the youngsters they are often allowed to go out of the fold after the flock has gone off for the day. They will then content themselves with nibbling the young grass and leaves within easy access of the pen, never leaving it to go any distance until their dams return at night. Where handled by experienced breeders roo per cent. of kids are often raised to the number of breeding does, the few losses being made up by twins, of which about 7 to Io per cent. are generally dropped in a flock of well-bred Angoras. The percentage of twins in well-bred Angoras is not as high as in a flock of common or native goats.

"The Angora goat," concludes Mr. Hughes, "is rapidly coming to the front as an important factor in the solution of the difficulty involved in the reclamation of our more mountainous districts, and bids fair to appreciably lessen the existing difference between the values of our low lying or level land, and those which, owing to their hilly and scrubby character, have hitherto been regarded as having scarcely any productive value."

\section{CHAPTER VI.}

\section{Views of a Veteran.}

Co1. William M. Landrum, the father of the goat industry in Texas, says: "Fifty years ago the Angora goat was all beauty and theory. We then knew very few facts concerning the animal. Now all the necessary experiments have been made and the goat has taken its place at the head of all grazing animals. The Angora finds its happiest home in mountainous districts and rough land, keeping in superior condition where other animals would starve. The Angora feeds upon five hundred different herbs in America. It has a larger percentage of increase 
than cattle or sheep and a greater value of fleece. When slaughtered its pelt is worth a good price, and Angora meat is the best of mutton. Kansas City buyers are taking all the good shipping wethers that can be found in Texas and New Mexico at from two to three dollars per head on the mountain ranges. They even take for feeders those that are not ripe for slaughter.

"Even on the low hills Angora goats are a success. My neighbor, J. D. Tracy, was for several years connected with an old wool house in New York, and came out to Texas for his health. After being here a while he bought a herd of common and very low graded goats, and came to my herd and purchased pure bred Angora bucks, to breed to them. The first clip gave him fleece enough to make a cushion for his wagon. As the flock increased he continued to get males from our flock. He has sold thousands of dollars worth of mutton and could now get $\$ 5,000$ for $\mathrm{x}, 000$ head. He has held close to the same bucks and the same line of pure breeds. He sheared in 1898 over 7,500 pounds of fleece and has extended his mountain range to 7,000 acres. He cleared at least $\$ 6,000$ in 1899 and will clear $\$ 7,-$ 000 in 1900 from flock. He bought the goats for company, and has thrown his money at the birds. He has made two trips to Europe and has plenty of goat money left. During all this time he has hired his herders and only made the business a matter of pleasure and health. His fondness for his mountain home and for his goats has grown until New York has lost its charm for him.

"In regard to the hardihood of Angora goats I will give the experience of B. D. Butler, of Oregon. He had a flock of 1,500 sheep and concluded to try goats. I sold him a lot of 500 head back in the seventies. He was owing me a balance of $\$ 500$ on the goats, and during the winter he wrote me that he had lost every animal he had in the world and was broke. He had camped his goats on the east side of the Cascades, about I4 miles from the mountains, and the snow storms had covered up his entire flock, goats and sheep, more than ten feet deep. His shepherd, he said, had barely escaped with his orvn life. In the following spring $\mathrm{Mr}$. Butler wrote me that as soon as the snow was gone he started out to find the remains of his flock. He dis- 
covered the carcasses of his sheep rounded up in a pile, but not a goat, hide or horn, was to be found. He proceeded up a gorge toward the mountains and after travelling some fifteen niles noticed that the fir and pine limbs were barked and many of the boughs eaten off. What was his astonishment to finally come upon his goats in green grass up to their knees and as fat as seals. Not a goat was lost out of the herd. They had wintered on at least forty feet of snow. I shall never forget the pleasure which he expressed in that letter assuring me that my goat money was safe.

"I will give another case in which the goat proved himself to be a mountain master. I sold a fock to a mining company on Feather River in California, up in the mountains, for their meat. Winter came on and the whole camp was snowbound. The snow was eighteen feet deep. There was, fortunately, an empty barn in which the goats slept at night. Every day they went to the mountains and fed upon the boughs of trees high above the earth, returning to the empty barn for shelter regularly when night approached. The goats kept fat all winter and furnished the miners with meat.

"While goats can stand any amount of cold and snow, sleet and wind are very injurious. On the other hand they can endure the scorching heat of the tropics. Their fleece is best at an altitude of from 3.000 to 6,000 feet above sea level. The fleece never sheds on the Guadalupe Island, 2 Io miles from San Diengo, at an altitude of only from 2,000 to 4,000 feet. I have grown mohair there two feet long, of lovely texture. We had 80,000 wild goats roaming on the island without any attention except in slaughtering season when we sheared the Angoras and slaughtered from $\mathrm{I}_{4}, 000$ to $\mathrm{I}_{5}, 000$ common goats for their hides and tallow. The goats all ran wild and took care of themselves. We were not at one dollar of expense on them.

"It may readily be seen what wild mountain lands, with their brush and briars, will be worth when they are utilized for Angoras. During the drought in Texas the Angora goat was the only animal you could go to a bank with and borrow money on. During the financial depression several years ago, nobody conld get the railroads to haul wool unless the charges were guaran- 
teed, but mohair was all the time selling at from twenty-five to forty-five cents a pound, saving South Western Texas and New Mexico from suffering."

\section{CHAPTER VII.}

\section{Angora Goats and Their History.}

The Angora goat is a native of Turkey in Asia. The Turks look upon the goat with feelings akin to reverence. Mahommed decreed a blessing upon all houses where a goat was kept and promised that if an angel should pass a house where three goats were maintained the angel would look in upon the household. Orthodox Turks believe to this day that goats bring peace and prosperity.

The province of Angora is mountainous and furrowed by deep valleys. The mean altitude is about three thousand feet. The climate is extreme. In January and February the thermometer ranges from ten degrees Fahrenheit to zero, while in June and July it remains in the eighties for days at a time with little or no rain. The country is covered with snow in winter. Rain and snow fall frequently.

While the more elevated masses are generally shaded with fine forests, the plateaus, which form a large part of the country, are very little wooded. This nudity permits the first heat of spring to dry up the little humidity which the earth has acquired in winter. Abundant pasturage is found for goats only after the frosts and snows, when the first warm rains revive the vegetation. This time is of short duration, and the stimulus given by copious and succulent nourishment is exerted wholly in developing the valuable fleeces. The hair or wool of the Angora is known as mohair. The shearing, which takes place in April, is hardly concluded when the vegetation called forth by the warm spring is arrested and dried up, receiving no moisture from the dews. This dryness gives to vegetation during summer an aromatic character which makes it peculiarly digestible and stimu- 
lating. The geological characteristics of the rocks which underlie the surface is similar to that of the mountainous districts of the United States, and it might be interesting to show the adaptability of the Angora goat to American highlands by scientific comparisons, had not the proposition been more conclusively proved by experience.

The modern Angora is a rugged breed formed by crossing the original Angora, a more delicate animal, with the Kurd or common Turkish goat. The success of such crossing is attested by all authorities, and the same policy has been carried out in America and South Africa in crossing Angoras with the common goats of each country.

S. C. Cronwright Schreiner, of South Africa, author of an up-to-date work on the Angora goat, recently published by Longmans, Green \& Company, affirms that the crossing of the original pure Angora with the Kurd goat in Asia Minor has eliminated the original Angora and substituted for it a made breed. "This breed," adds Mr. Schreiner, "which is not yet quite fixed, but is gradually tending to become so, is a larger, somewhat coarser, hardier breed, with an oilier and much heavier fleece, which, though not attaining to the high level of that of the original pure Angora, is nevertheless in the best specimens of great beauty and excellence, and equal to the most exacting demands of the present mohair manufacturing trade. As the fleeces combine with increased weight a sufficiently high standard of excellence, and as the goat is hardier and healthier, it is the more remunerative breed; and when stable at the high standard it has attained to in the hands of the most intelligent breeders, it is superior and preferable to the original pure breed."

The Angora goat was first introduced into the United States from Turkey in 1848. During the Administration of President Polk, the Sultan of Turkey requested that a suitable person might be sent to that country to conduct some experiments in the culture of cotton. Dr. James B. Davis, of South Carolina, was selected to perform this important service. On his return to the United States the Sultan, desiring to show his appreciation of the President's courtesy, caused nine of the choicest goats of Angora to be presented to Dr. Davis. Of these, eight reached America-two bucks and six does. They 
were kept by Dr. Davis on his farm near Columbia, and seem to have been of a particularly excellent quality. It is reasonable to suppose that the conditions under which they were acquired implied a guarantee of their excellence. This suggestion is borne out by the opinion generally held of them in America as compared with subsequent importations. These goats were afterward purchased by the late Colonel Richard Peters, who secured them for his farm at Atlanta, Georgia, where he pursued the industry with conspicuous intelligence and enthusiasm. Colonel Peters is known as the father of the Angora industry in America, and time and the experience of others have verified the accuracy of his judgment in questions of management.

It will thus be seen that the personal gift of the Sultan became the foundation of the Angora goat business in the New World. The record of subsequent importations is not entirely complete, but according to the best information obtainable, about four hundred Angoras were brought to America from their native land up to I880, when the Sultan issued an edict prohibiting further exportations from his dominions as injurious to Turkish mohair interests.

The standard American book on the Angora goat was written in 1882 by John L. Hayes, LL. D., Secretary of the National Association of Wool Manufacturers and a naturalist of acknowledged authority. Dr. Hayes is convinced that the Angora goat is completely acclimated in the United States, and the race appears to have been actually improved in this country in favorable locations and under intelligent culture. The notion insisted upon in Asia Minor, and formerly entertained here, of the necessity of a high altitude for the successful culture of the Angora, appears to be negatived by experience in this country and else-where. An indispensable condition of success in the Angora husbandry in this country is a provision of acclimated stud flocks of thoroughbred bucks and ewes for regenerators, meaning, by thoroughbred, Angoras imported from Asia Miror of unquestionable selection, and their progeny. The most rapid and advantageous method of forming largeflocks of Angoras is bycrossing thoroughbred Angora bucks upon common does, and the does of the resulting product, with the object of merging the common race in the superior. Good results are obtained at the 
fifth cross. It is indispensable that thoroughbred bucks should be invariably used for propagation. Millions of acres of land in this country unsuitable for sheep husbandry may be advantageously occupied by flocks of Angoras, which may be grown at half the cost of sheep in their most favorable locations, and with at least an equal return in the product of the flocks.

In discussing the adaptation of Angoras to the climate, soil and means of sustenance of the United States Colonel Peters is quoted as saying that the comparative dryness generally of our climate removes the most formidable obstacle to their culture which has been found in Great Britain and the contingent of Europe. Except in those localities where excessive moisture prevails, there are no climatic obstacles to the culture of Angoras in the United States. "Angoras," says Colonel Peters, "being not properly grazing animals, like sheep, require for their health ful sustenance bushes, briers and weeds. In summer, fall and spring my flocks are allowed an extensive range through fields of grass and woodland fenced in. At these seasons they are not sheltered during rain, but return every evening to their 'roosting' places, near their winter sheds. The flock, starting in the morning after sunrise, goes forth to its range, each goat taking a bite of grass or of weeds as the flock scatters through the woods, proceeding gradually from their home until they fill themselves. After this they lie down and ruminate, and sleep for several hours. Then they commence their homeward march, feeding as they go along, and arriving at their evening quarters at about sunset, lie down in the open air, remaining quiet until after sunrise the following morning."

\section{CHAPTER VIII.}

Angora Goat Products.

William R. Payne, of New York, the best known dealer in mohair and goatskins, writes: "The Angora goat has only been cultivated in this country about fifty years. Few people know its value and fewer still know that mohair is the fleece of this animal. The Angora has not yet obtained a status in agricul- 
tural journals. Yet it is one of the most valuable of animals, for its fleece, pelt and carcass, and one of the easiest and cheapest to cultivate. There are in the whole country now probably about 300,000 head of Angoras including all degrees of blood near and remote. Of these, probably not over one-third can be called 'high' grade even by courtesy. Of pure blood there is none, except possibly a flock in a remote region, which has been kept intact from cross-breeding, but has been inbred since 1876 . Of imported animals from Turkey since 1849 there have come into the country so far as records show, about 350 Angora rams and ewes, many of them of doubtful blood. Of really high character and grade probably not over thirty rams, all told, have come from Turkey. From this foundation has been bred up the present stock. Between cross-breeding and in-breeding whatever pure blood there was has been pretty well eliminated, and the crying need now is for good, pure, sound, first-class fresh bucks, a registry farm and a new start. It needs some brains, energy and money put into it, to make it one of the best paying industries there is. Unfortunately, the constituency behind the Angora in the United States to-day has not a large vote like that back of the sheep. Up-to-date it has been treated like any old goat in Shantyville-as not worth the stone that is thrown at it. It is impossible to get animals from Turkey without a strong pressure from government and diplomatic sources.

"The most important product of the Angora is the long silky, wavy fleece used either pure or in connection with wool, silk, linen or carlton, in a variety of fabrics for house-furnishing and ladies' goods, brilliantines, linings, braid, plushes, astrachan cloth, furniture coverings, curtain material, knit goods, fancy effects in shawls and dress goods and numerous other textiles. Its value ranges for foreign, from forty-five to fifty cents a pound, and for domestic, from twenty-five to thirty-five cents. There are consumed annually here about $I, 000,000$ to $I, I 25,000$ pounds, of which the bulk has to be imported, as only about 250,000 to 300,000 pounds of the domestic product are long enough and of character to suit manufacturing needs. The short, low and cross-bred hair is used for blankets, lap-robes, rugs, carpets and low goods generally, but even then is worth more per pound than most sheep wool, varying from ten to twenty-one cents. The uses for mohair are increasing every year and new outlets 
are being found for it as manufacturers are advancing in the variety of their products.

"Angora skins properly dressed are used white or tinted to manufacture rugs, robes, carriage mats, fur sets for children, trimming for ladies' furs, and, also, for dusters, horse-head tassels, doll hair and wigs. They are mostly imported raw from the Cape of Good Hope and Turkey, and range in value, duty paid, from $\$ 1.50$ up to $\$ 3.50$ each, undressed. Domestic skins are in very limited supply, and are worth from 50 cents each for kids up to $\$ 2$ each for large full-fleeced pelts. The low, cross-bred, common skins and short pelts not suitable to dress are used by morocco and glove leather manufacturers, and are worth from I 5 to I8 cents a pound for large sizes, down to Io and I cents for small ones and kids. The flesh of the Angora is said to be excellent mutton and pronounced as good as Southdown. It is quite largely eaten in the West and in the East also, if people only knew it. There is a prejudice against the name of goat meat, but those who know say it is very good. The horns can be utilized in a variety of ways, and not a part of the animal but has a value.

"We may add that the climatic conditions and food supply of a large part of our mountainous country is admirably adapted to Angora ranges, and there is not a State in the Union, east or west, in which they cannot be grown to good advantage. Another point is that notwithstanding the inbreeding, cross-breeding and inability to get fresh blood, American ranchmen have improved the stock they had to work with, just as they improved the original Merino sheep, and believe, if given the material to do with, they will in time produce a better animal, larger and finer, than the original stock with nearly 3,000 years of history behind it."

\section{CHAPTER IX.}

\section{Milk Goats.}

While the aristocratic Angora is in many respects the most fascinating of the goat species, there are other varieties equally 
hardy in character and especially valuable for their milk and skins. Milk goats are most generally raised in England, Ireland, France, Sivitzerland and the Island of Malta. Uut of goat milk are made Roquefort, Mont D'Or, Le Sassenage, Levroux and many other favorite cheeses. The milk of the goat is rich and easily digested, and wholly free from the diseases which frequently affect the milk of the cow.

The British Goat Society, of which the Baroness BurdettCoutts is President, is doing a great work in the encouragement of goat raising throughout the United Kingdom. The purposes of the society are set forth as follows: "This society has been instituted in order to bring more prominently forward the utility and adaptability of the goat as a milk supply. It is a well established fact that in rural districts the families of the poor rarely taste other than skim milk, in consequence of the difficulty of procuring the pure article as it comes from the cow. It is either sent wholesale to London or the nearest town, or utilized at once in the manufacture of butter and cheese. On the continent and in Ireland the goat is regarded as the poor man's cow, supplying as it does many a peasant family with this most important article of diet, the deficiency of which, among our own laborer's children must act detrimentally in regard to their physical development. The goat is especially adapted for such a purpose. It supplies just enough milk for the ample requirements of an ordinary household during the greater part of the year, and as it eats with avidity almost every kind of herb and vegetable, and is besides of a hardy nature, it is kept with little trouble and at almost nominal expense."

The prevalence of tuberculosis in cows is a cause for alarm, and the attention of the medical fraternity and the general public is attracted to the utility of goat milk. Consumption of the bones or some particular organ of the body frequently results from taking into the system milk from tuberculous cows.

In a recent address before the Huddersfield Technical College in England, Sir William Broadbent said: "Cows are very subject to tuberculosis, and at a certain stage of the disease tubercle bacilli are present in the milk. It is through milk so contaminated that children come to have tuberculous disease. The disease of bones and joints to which children are subject are 
probably also traceable to milk; humpback, hip-joint disease, and the diseases of knees, elbows, etc., which cripple so many children; perhaps so is lupus, and no doubt tubercle is often implanted by milk in early life, which develops later into consumption."

Sir William Broadbent subsequently goes on to say: "It is interesting to note that asses and goats do not suffer from tuberculosis, and to bear in mind that the shrewd physicians of past days used to order asses' and goats' milk for persons threatened with consumption."

H. S. Homes Pegler, Secretary of the British Goat Society, and author of the "Book of the Goat," in speaking of Sir William Broadbent's address, says: "In France this subject has received more attention. Professor Nocard stated some seven or eight years since that out of $\mathrm{I} 30,000$ goats and kids brought to Paris for slaughter at the shambles of La Villette every spring, the meat inspectors of that city failed to discover a single case of tuberculosis. He even added that inoculation fails to introduce the fatal bacillus into the system of the goat, although I believe the statement has since been questioned; any way, I have been told by veterinary authorities in this country that attempts made in England have failed. Goats' milk as a diet for children has many advantages over cows' milk, as I have often demonstrated, but this one great virtue transcends all others, and it is inconceivable that parents knowing this, and having the opportunities and accommodation for goat-keeping, should not avail themselves of so simple and economical a means of at once providing their children with the most easily digestible and most nourishing of food, and safeguarding them from one of the greatest evils that civilization of the present day is subject to."

Dr. Adolph H. Allshorn, Licentiate of the Royal College of Physicians, Licentiate of the Royal College of Surgeons, and Physician to the Homeopathic Hospitals, Manchester and London, says: "As a substitute for the mother's milk to children deprived of that necessary, goats' milk has no equal, and notwithstanding. the similarity in composition (as revealed by analysis), no one who has seen its effects can doubt its superiority to cows' mill. In diseased conditions of infancy, when there is a tendency to deficient assimilation in tubercular disease, Rachitis, Exophthalmic Goitre, I have proved its success, and have succeeded in rearing 
a third or fourth child of a family, the previous children of which have died in infancy from hereditary disease. Children brought up on goats' milk for a time after weaning from the mother will compare more than favorably with those brought up under like conditions on cows' milk. I believe that goats' milk in senil conditions is of the utmost value, and know that it has a retarding effect in cases of Atheroma, whether this is due to the peculiar acid (Hircie) which it contains I am unable to say with certainty."

The successful crossing of milk goats with Angoras is believed by many to be practicable. Dr. Hayes publishes in his book a letter from J. W. Watts of South Carolina, who gave his experience as follows: "Even here, seventy-five miles from the mountains, I have for six years grown most successfully the Angora goat, whose flesh I regard as superior to any mutton, and whose fleece properly handled could in the Blue Ridge Mountain region be made more profitable than any wool growing. This I can say from actual experience with Angoras, which are of Asia Minor stock, meeting here few obstacles to their profitable breeding, and which in the Blue Ridge just beyond me would find an exact counterpart of their native soil and climate. Aside from their flesh and wool there is another advantage they offer, which in the mountains beyond would be most valuable. In a cross I have made with a pure Angora buck and a Maltese ewe goat I have raised a ewe goat that will give four quarts per day of as good milk as any cow on my plantation. The feed of one of my cows will keep twelve goats. My cows must have certain food or they will not thrive. My goats will eat anything, almost, and do well, and with this advantage, also, that their milk and butter are not in any way affected by their diet."

\section{CHAPTER X.}

Starting In the Goat Business.

George A. Hoerle of New Jersey, well known as Secretary of the American Mohair Growers' Association, and himself an experienced and scientific breeder, is a firm believer in the An- 
gora goat industry in the United States. There are very few States in the Union, says Mr. Hoerle, which have not millions of acres of brushy mountain land of next to no value located from an altitude of 400 or 500 feet above the sea level to 6,000 or 8,000 feet, depending much upon the latitude of the land, which would offer a perfect paradise to the Angora goat, and would if stocked with these animals be a source of ever increasing profits to their owners, and the amount of money which would be required would be so low compared to the profits which could be realized by an intelligent caretaker that the cost usually should not be in the way of anybody who wishes to engage in the enterprise.

The farmer whose farm partly consists of scrub mountain land would have the advantage, and to him Angora goats would be entirely supernumerary, offering the greatest chances for large profits. All he has to do is to fence a piece of land into two pastures, turn his goats on them alternately, sometimes in one, sometimes in the other; drive them out at daybreak and bring them back at sundown. If possible he should connect the pastures with his barn, where he should construct an open shed or hovel. Anything that will turn rain would be sufficient. Upon arrival at their roosting place feed them some little grain, and they soon will not have to be driven in any more, but be there in time for the sweet morsel.

The owner of Angora goats should procure at kidding time two or three suckling pups of some strong breed of dog, but if possible with a strain of collie in them, and raise these pups on a kidless doe (a common one would be preferable) until they are large enough to follow the goats. Such dogs will become so attached to the breed of their foster mother that they will fight for them until death anything in the shape of four or two legged curs that would venture near their charge and be the most reliable of shepherds. Two or three dogs thus brought up with goats could be trusted with the management of a flock of sheep of as much as two or three thousand, and with very little extra instruction would herd them as well and with as much sense of duty as any hired shepherd and be far cheaper. I am often asked questions in regard to the cost of goats and whether common goats or Angoras would pay best for a start.

Common goats are not high in price, but the item of freight is considerable. This cost may be ascertained from the nearest 
railroad agent. It is only natural that for goats yielding very heavy fleeces very large prices should have to be paid, and of course also to the above prices the freight would have to be added.

But the Angora goat industry must to-day be considered a very safe and at the same time very profitable investment, provided the personality of the new beginner is suited to it, and if his means are adequate to his own personal demands or those of his family. The land is steadily increasing in value, and his stock is constantly improving. Thus his income as well as his property will steadily increase.

The goat industry promises to furnish a solution of some of the problems which have baffled the wisest statesmen and sociologists. The utilization of $265,000,000$ acres of now worthless land is in itself a proposition which challenges the broadest comprehension. The worn-out farms of New England, never noted for superior fertility, afford a rich field for goat raising, and the disheartened descendants of the Puritans may here find profitable and permanent occupation suitable to their impaired means and ambitions.

Scrub lands are especially prevalent in southern localities where the lower negro element is thickest. Goat herding would be an occupation more congenial perhaps to these indolent people than any other, while it might be a valuable factor in their regeneration. While skill is a good thing, even in goat raising, it is certain that unskilled labor is more available in this industry than in any other, and the influence of the goat upon American social conditions may soon lead us to look upon this animal with appreciation. We may even understand why the goat was an cbject of worship among many ancient people. 
d

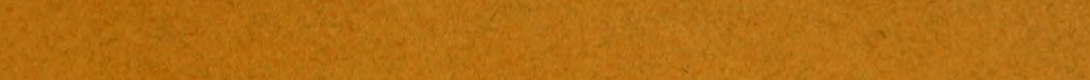
Fy

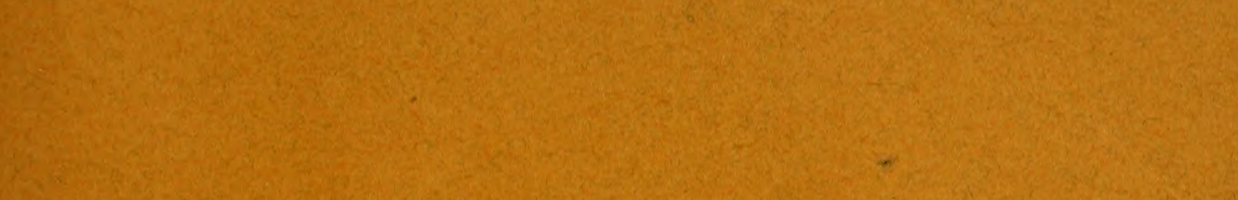

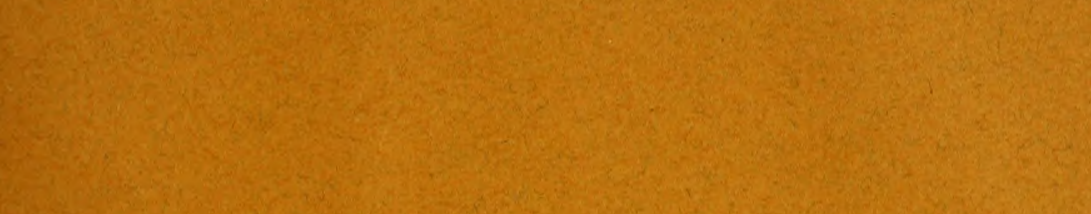

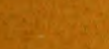

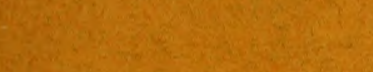

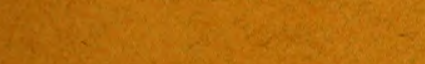

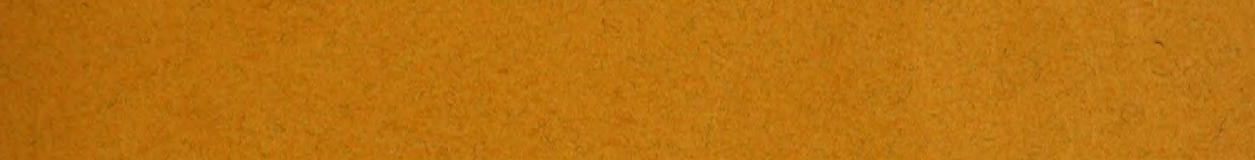

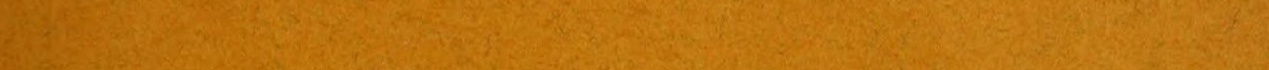

S.

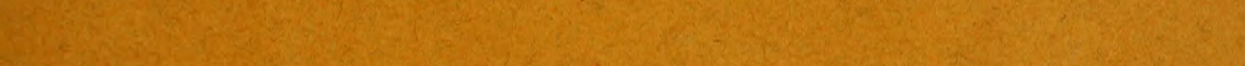
(2) What

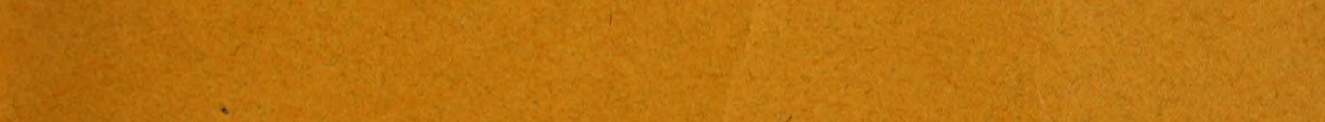

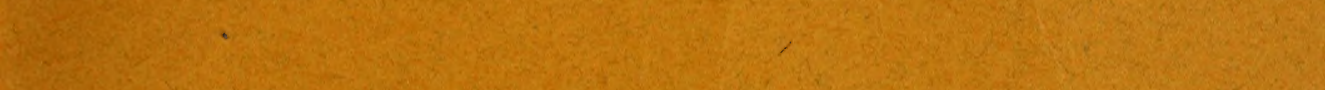

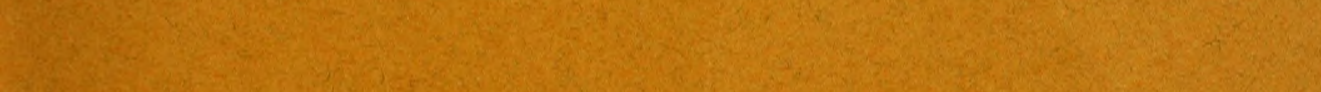

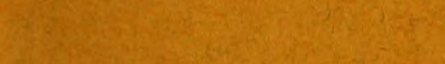
(x). 
LIBRARY OF CONGRESS ||| || || || |||||||||||||||||||||||||||| 